ISSN 0819-2642

ISBN 0734016816

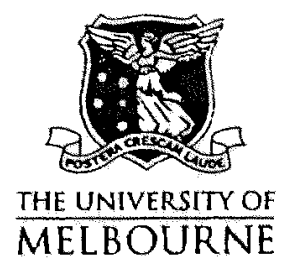

THE UNIVERSITY OF MELBOURNE

DEPARTMENT OF ECONOMICS

RESEARCH PAPER NUMBER 740

MARCH 2000

Interrelationships between Income, Health and the Environment: Extending the Environmental Kuznets Curve Hypothesis

\author{
by \\ Lata Gangadharan \\ $\&$ \\ Ma. Rebecca Valenzuela
}

Department of Economics

The University of Melbourne

Melbourne Victoria 3010

Australia. 


\title{
Interrelationships between Income, Health and the Environment: Extending the Environmental Kuznets Curve Hypothesis ${ }^{+}$
}

\author{
Lata Gangadharan \\ Department of Economics \\ University of Melbourne \\ Victoria 3010, Australia \\ and \\ Ma. Rebecca Valenzuela \\ Department of Economics \\ Monash University \\ VIC 3168, Australia
}

April 2000

\footnotetext{
We would like to thank Pete Summers and the participants at the Conference of Economists, 1999 for their comments. The usual disclaimer applies. Funding for this research was provided by the Faculty Research Grant Scheme, Faculty of Economics and Commerce, University of Melbourne.

${ }^{+}$Contact addresses: gangadha@cupid.ecom.unimelb.edu.au, Rebecca.Valenzuela@buseco.monash.edu.au
} 


\begin{abstract}
This study examines the link between the health indicators and the environmental variables for a cross-section of countries widely dispersed in the economic development spectrum. While environment and income are seen to have an inverted U-shaped relationship (Environmental Kuznets Curve hypothesis), it is also well established that health and environment are positively related. Our study focuses on the implications of this for the relationship between health and income. In the early phases of income growth, the gains in health and the losses in environmental quality could cancel each other out and this challenges the idea that as incomes increase health would always improve. To empirically analyse these issues, we estimate a two-stage least squares model that focuses on the impact of income and the environment on health status, with $\therefore \quad$ environment being an endogenous variable. Our results show that the environmental stress variable has a significant negative effect on health status. At the same time, GNP levels and improvements in access to better sanitation and safe water are shown to vary positively with health status variables. We find that the health gains obtained through improved incomes can be negated to a significant extent if the indirect effect of income acting via the environment is ignored. Research findings in this regard would be a useful policy instrument towards maximising both the environmental and health gains that come with economic growth and development.
\end{abstract}

Keywords: Environmental Stress, Health Indicators, Income Levels JEL Classification: O11, Q25, C30 


\section{Introduction}

Is economic growth part of the solution rather than the cause of environmental problems? This question has been raised very often in recent years as empirical evidence in support of the Environmental Kuznets Curve (EKC) hypothesis mount. The EKC (Grossman, (1995), Grossman and Kreuger, (1995)) describes the relationship between declining environmental quality and income as an inverted $-U$, that is, in the course of economic growth and development, environmental quality initially worsens but ultimately improves with improvements in income levels. Torras and Boyle (1998) show that the level of air pollutants (sulphur dioxide and smoke) peak at a per capita income in the neighbourhood of US $\$ 4000$.

One of the explanations for the EKC relationship is that environment can be thought of as a luxury good. In the early stages of economic development a country would be unwilling to trade consumption for investment in environmental regulation, hence environmental quality declines. Once the country reaches a threshold level of income, its citizens start to demand improvements in environmental quality and this leads to the implementation of policies for environmental protection and, eventually, to reductions in pollution. Increasing levels of pollution are thus strongly associated with both poor and developing economies, while declining levels of pollution are more commonly observed for their developed counterparts.' Another explanation of the EKC hypothesis is that countries pass through technological life cycles, as they move from agriculture-based economies to service-based systems. As the service sector is associated with lower environmental

\footnotetext{
${ }^{1}$ For example, Grossman and Kreuger (1995) found evidence in support for the EKC hypothesis for 12 of the 14 air and water quality variables for a cross section of countries.
} 
impact, this transition from high polluting to low polluting technology leads to less environmental stress. Hence in the long run, pollution levels are expected to improve with incomes. This has been used to justify the pursuit of growth strategies that do not give due consideration to their effect on the environment.

In this paper, we argue that this strategy is not justified and provide some related evidence to support our case. We test the hypothesis that larger economic and social gains can be attained by an economy if the growth strategy adopted incorporates, rather than ignores, environmental concerns. To do this, we include health as the intervening variable in the analysis. While environment and income are seen to have an inverted Ushaped relationship, it is also well established that health and environment are positively related. What does this imply for the relationship between health and income? It is possible that in the early phases of income growth, the gains in health and losses in environmental quality cancel each other out and this challenges the idea that as incomes increase, health would always improve.

In view of the above, we argue in this paper that the recorded health gains brought about by the improvement in income levels do not represent the total realisable health benefits from having higher per capita income. Without the appropriate environmental protection policies, damages to a country's physical environment are incurred during the process of income growth and economic development. This negatively affects the health and well being of individuals in the country and the aggregated impact could negate some of the health gains already derived and hence dampen achievement levels in the health area. If 
we find that this argument has some empirical support, it would imply that development policies addressing environmental issues are effectively also addressing the health issues of the economy. In that case, policies that pursue economic development cannot afford to ignore environmental issues, particularly in the early phases of economic development.

We look at recent evidence from a cross section of countries to determine if this is indeed the case. There have been some studies (e.g. Cropper et.al, 1997), which look at the incidences of air or water pollution related diseases in a particular region or country. : However, this is one of the first papers to study the link between the health indicators and the environmental variables for a cross-section of countries widely dispersed in the economic development spectrum.

The major contributions of this paper are the following:

1) To establish the link between health and environment. While this link has been suggested before, to the best of our knowledge it has not been explored for different countries.

2) To explore the differential impact on health of several environmental stress variables. The standard practice is to focus on just one variable. normally $\mathrm{CO}_{2}$ emissions. We attempt to make our findings and conclusions more robust by including several other pollutants and environmental damage indicators in the analysis.

3) To analyze the shape of the EKC curve and the health relationship using alternative functional forms to determine which among them best fits the data. 
The rest of the paper is organised as follows. Section 2 surveys the related literature on the relationship between income levels and environmental stress and the link between income levels and health status. Section 3 describes the analytical framework and the methodology used in the paper. Section 4 summarises the data used in the analysis. Section 5 discusses the results from the estimation and Section 6 concludes.

\section{Related Literature Survey}

Grossman and Kreuger (1992), Panayotou (1993) and Selden and Song (1994) presented initial evidence that some pollutants follow an inverted- $U$ shaped curve with respect to income. This was widely interpreted (for example, World Bank, 1992) to mean that the surest way to improve a country's physical environment is to increase income levels. More recent work has focused on factors other than income as explanatory variables in analysing variations in environmental stress in different countries. Kaufman et al (1998), Torras and Boyce (1998) and Suri and Chapman (1998) argue that the EKC's previously estimated could be due to important missing variables. Kaufman et al (1998) stress the importance of spatial intensity of economics activity. Torras and Boyce (1998) explore the effects of social factors like civil rights, income inequality and education, while Suri and Chapman (1998) find that trade-related variables have significant explanatory power. Most of the papers mentioned use linear or a log linear functional relationship between emissions and income. An exception is Galeotti and Lanza (1999), which studied relationships based on the gamma distribution. The current state of the research on the EKC is unable to conclude if the EKC-hypothesis is confirmed or rejected. 
With regards to health, there exists a large literature that has studied the relationship between income and health using cross-country data. A number of previous studies in this literature have found a significant and negative income elasticity of infant mortality rate (see for example, Pritchett and Summers, 1996, Hill and King, 1992, Subbarao and Raney, 1995, Flegg, 1982, Parpel and Pillai, 1986 and Kakwani, 1993). Similarly, research on life expectancy and income has shown that there is a positive relationship between increases in income and life expectancy, with income elasticity of life expectancy estimated to be significant and positive (Preston, 1980, Hill and King, 1992).

: Most of these studies do control for other factors that affect health status such as the accessibility of health services and education levels of the population.

\section{Analytical Framework}

In this paper, we are interested in how the interplay between income and the environment affect the health outcomes of a population. Generally, it is assumed that health outcomes for a population improve as the economy grows and develops. Such improvements are facilitated by the rise in general standard of living, including improved access to educational opportunities and health services. One's health is also seen as dependent on the quality of his or her physical environment - such as the amount of air pollution or the quality of drinking water. At the same time, the quality of a country's physical environment is a result of certain growth factors in the economy. These include, for instance, the more intensive use of land, forest and water resources to increase overall economic production. Air pollution levels are also bound to increase as production levels rise. Increase in population numbers is another important factor in this context. 
The relationships discussed above are summarised in the following general model:

$$
H_{i t}=f\left(X_{i t}, E_{i t}\left(X_{i t}, Z_{i t}\right), W_{i t}\right)
$$

which states that an economy's health status $\left(H_{i t}\right)$, depends on its level of economic development $\left(X_{i z}\right)$, on the quality of its environment $\left(E_{i t}\right)$ and other social factors $\left(W_{i t}\right)$ including, the provision and access of health facilities and services, $Z_{i t}$ is used to denote the factors that determine the quality of the environment. Under this framework, we test the relevance of the EKC hypothesis, captured in the term $E_{i t}\left(X_{i t}, Z_{i t}\right)$, and how it impacts on the health outcomes for a country's population.

To be able to empirically analyse the issues at hand, the following econometric model is formulated for country $i$ :

$$
\begin{aligned}
& E_{i t}=\beta_{0}+\beta_{11} X_{i t}+\beta_{12} X_{i t}^{2}+\beta_{13} X_{i t}^{3}+\beta_{2} Z_{i t}+e_{i t} \\
& H_{i t}=\alpha_{0}+\alpha_{11} X_{i t}+\alpha_{12} X_{i t}^{2}+\alpha_{13} X_{i t}^{3}+\alpha_{2} E_{t t}+\alpha_{3} W_{t t}+h_{i t}
\end{aligned}
$$

where $E_{i t}$ refers to the overall level of environmental stress in the economy;

$H_{i s}$ refers to the level of health status of the population;

$X_{i t}$ pertains to the country's level of economic development;

$Z_{i t}$ are variables that impact on the quality of the physical environment;

$W_{i t}$ are variables that directly influence health such as provision and access to medical facilities etc;

$h_{i t} e_{i t,}$ are random error terms;

$t$ refers to the two time periods studied: 1995 and 1980 .

$n$ refers to the number of countries in the study.

Equation (2) is the Environmental Kuznets Curve with economic development indicated by the country's gross national product. The inverted-U EKC requires $\beta_{11}$ to be positive 
and $\beta_{12}$ to be negative. A cubic income term is added to test the proposition from recent research that environmental quality tends to decline once again with extremely high incomes. The upward bend of the Kuznets curve at the very high income levels will be captured by the $\beta_{13}$ term, which is expected to have a positive sign. The $Z_{i t}$ variables capture the effects of population size, literacy level and inequality in the income distribution in the economy. Equation (3) relates health with the country's income level $X_{i t}$ and such factors that directly influence health including availability and accessibility of health care services, level of sanitation, child immunization rate and so forth. The quality of the physical environment is also included here as an endogenous variable in the system.

In the above model, the structural equations are clearly identified given that $E_{i t}$ and $H_{i t}$ are the only endogenous variables in the system while the rest $\left(X_{i t}, Z_{i t}\right.$ and $\left.W_{i s}\right)$ are taken to be exogenous. By substituting equation (2) in equation (3), we derive the reduced form equation for health:

$$
H_{i t}=\pi_{0}+\pi_{11} X_{i t}+\pi_{12} X_{i t}^{2}+\pi_{13} X_{i t}^{3}+\pi_{2} E_{i t}+\pi_{3} W_{i t}+v_{i t}
$$

where

$$
\begin{array}{lll}
\pi_{0}=\alpha_{0}+\alpha_{3} \beta_{0}, & \pi_{11}=\alpha_{11}+\alpha_{3} \beta_{11}, & \pi_{12}=\alpha_{12}+\alpha_{3} \beta_{12}, \\
\pi_{13}=\alpha_{13}+\alpha_{3} \beta_{13}, & \pi_{2}=\alpha_{3} \beta_{2}, \quad \pi_{3}=\alpha_{3} & \text { and } \quad v_{t i}=\alpha_{3} e_{i t}+u_{i t} .
\end{array}
$$

Note that the structural and reduced forms of the environmental equation component of the model are identical because the right hand side variables are exogenous to start with. The reduced form equations are then estimated using general two-stage least squares 
estimation methods. The results obtained are subjected to a robustness test with regards to functional forms and to different assumptions made regarding the type and nature of the variables used. The coefficients from the estimated equations will indicate if environmental variables play an important role in improving health outcomes in a country.

\section{Data}

There are a number of environmental stress variables that are available for analysis. The most common air pollutants for which data are available relate to such activities as commercial energy production, efficiency in energy use, and gas emission levels. For water pollution, the World Bank provides data on emission levels of organic pollutants as well as information on industry shares. Limited data on land use and deforestation rates have also been, derived from the World Bank.

The link of the environment with the country's level of economic development is analysed using common indicators such as GNP and GDP (in per capita terms). We also include population density levels, the degree of urbanization, the level of education, schooling rates of children, and the gap between the rich and the poor as measured by the Gini coefficient as explanatory variables.

The main health status indicators used are life expectancy and infant mortality rates. Life expectancy is a popular indicator of health although it is not without problems. Feachem et.al (1992) show that the causes of death in adults are much less likely to decrease with 
increases in per capita income; it may, in fact, increase. For example, many adult deaths could be due to motor vehicle accidents, use of tobacco and alcohol, excessive consumption of food products related to heart disease, and all these tend to rise with income. Infant mortality is a good alternative indicator as it avoids the potentially more severe reverse causation problems associated with the relationship between adult health and income growth. The mortality rate of children under 5 years of age is usually used as an indicator of child well being (UNICEF 1991, 1992). This welfare measure is used as another main health indicator in this study.

\section{Summary Statistics}

The empirical analysis here is performed on two sets of cross section data, pertaining to the years 1980 and 1995 . For the 1995 data, the 51 countries are spread across the various regions of the world; namely, Africa, Asia, Eastern Europe, Latin America, the Middle East, North America and Europe. From Table 1, it is seen that there is a high representation of countries from the advanced countries in Europe and North America (about $43 \%$ ) but this is balanced by a good coverage of countries from other regions with around $6 \%$ African countries, 18\% Asian, 16\% Eastern European, 13\% Latin American and $4 \%$ of the sample from the Middle East. In addition, the population coverage of the study is deemed good with the inclusion of China and India in the analysis. The complete list of countries covered is provided in Table Al of the Appendix. The 1995 coverage of countries has markedly improved over that for 1980, where there was a significant underrepresentation of countries from the Eastern European block. 
In the second panel of Table 1, countries are grouped according to whether they are low, medium or high income economies. Using purchasing power parity (PPP) Gross National Product (GNP) per capita for income, a low income economy is defined as those countries with per capita income below $\$ 5000$ PPP dollars; a medium income economy has income between $\$ 5000$ and $\$ 12000$ PPP dollars and those in the high income category have per capita income exceeding $\$ 12000$ PPP dollars. About $45 \%$ of the sample for 1995 consists of high income countries, $31 \%$ medium income countries and $24 \%$ low income. The 1995 data set has more countries in the middle income range compared to the 1980 set, which is dominated by low income economies.

The variables used in this study are listed in Tables $2 a-2 d$ along with some summary statistics. Asia is the most populated among the group of countries, mainly because of the inclusion of China and India in this grouping. As life expectancy is related to income, we see in our data that this is lowest in the poor African region and is highest in the more affluent economies of the Europe and North America. Likewise, gross enrollment ratio is extremely low for Africa, followed by Latin America countries.

For all the countries covered in 1995, the average rate of infant mortality is about 18 deaths per 1000 live births. However, this rate shoots up to 59 deaths per 1000 live births in Africa and 44 deaths per 1000 births in the Middle East. The African rate is extremely high, and far exceeds the average levels computed for all the other regions - more than double the rate for Asia and Latin America and seven times higher than that of the 
advanced countries of Europe and North America. The Gini coefficient is highest in Latin America and Africa, and lowest for Europe and North America.

Carbon dioxide emissions per capita $\left(\mathrm{CO}_{2}\right)$ and commercial energy use per capita (ENPC) are very high for richer countries compared to low-income countries. However when we compare the data for 1980 with the data for 1995 , we find that the carbon emissions and the commercial energy use per capita has increased only slightly for the high-income countries, but the same has increased substantially for the low-income countries. This could reflect the sectoral shift from agriculture to industry that occurred in the developing economies during this 15-year period. Other air pollutants like sulphur dioxide $\left(\mathrm{SO}_{2}\right)$, nitrogen dioxide (NO) and total suspended particulates (TSP) are significantly higher for low-income countries than for high-incomes countries in the 1995 sample. This could be due to the fact that richer countries have already in place environmental regulations targeting these pollutants, while this has yet to be implemented for poorer countries. Water emissions (EMW) and deforestation rate (DEFRTE) are much higher for low-income countries for similar reasons.

Due to lack of data some countries had to be deleted from the list to be able to perform the analysis for the 1980 sample. $^{2}$ For this data set, information on $\mathrm{CO}_{2}$ emissions and energy usage are available for only 36 of the 51 countrics in our study. There is also no available data on TSP, $\mathrm{SO}_{2}$ and $\mathrm{NO}$ levels and DEFRTE per country for this year. All the other variables are available for 1980 , except for the Gini coefficient. To be able to compare results across the two years, we estimated the equations using the available data 
on the Gini coefficient (for the year 1995) for the 1980 analysis. This assumes that levels of relative inequality have not changed much over the 15 -year period covered by the study and hence one should exercise caution in interpreting the results for inequality. The variable child (under 5) mortality rate is also incomplete for this year. Notwithstanding these data constraints, we still have a good mix of developed and developing countries for the 1980 analysis. The distribution and the summary statistics for this sample are presented in Tables $2 \mathrm{c}$ and $2 \mathrm{~d}$.

Table 3 presents the correlation between the various environmental indicators. $\mathrm{CO}_{2}$ cmissions and ENPC reflecting energy consumption levels are noted to have a very high positive correlation, while ENPC and $\mathrm{CO}_{2}$ emissions have a weak negative relationship with the emission levels of $\mathrm{SO}_{2}$, TSP and $\mathrm{NO}$, which are local pollutants. This may be a bit surprising as we would expect that a rise in energy consumption would be accompanied by a rise in pollutant emissions. Suri and Chapman (1998) explain this seemingly inconsistent result by suggesting that it is possible for energy consumption to keep rising but for emissions levels of local pollutants to fall, as would be the case when end-of-pipe technology like scrubbers and catalytic converters are used to reduce local pollutants. As the existing policies to abate local pollution are very often concentrating on end-of-pipe methods and not on reducing energy consumption or finding more effective pollution reducing technologies, we should not be surprised that energy use and $\mathrm{CO}_{2}$ emissions are not being reduced along with reductions in the levels of local pollutants.

\footnotetext{
${ }^{2}$ See Table Al for the countries excluded from the 1980 estimation.
} 


\section{Results}

Table 4 presents results from the estimation of the environmental equation, Equation (2) above. It is seen that income, population density and the level of economic inequality have significant influences on a country's level of environmental stress. Also, the F test shows that the coefficients are all jointly significant. The results are especially strong when $\mathrm{CO}_{2}$ emissions and ENPC are used as the dependent variables. In as far as $\mathrm{CO}_{2}$ emissions are concerned, results indicate that a $\$ 1000$ increase in per capita GNP increases the per capita $\mathrm{CO}_{2}$ emission level by 2 metric tons, where all other influences are taken to be constant. As shown in Figure 1, the increase in the per capita level of $\mathrm{CO}_{2}$ emissions diminishes with income and eventually plateaus at an income level of $\$ 13528$. After this point, we observe that large rates of increase in $\mathrm{CO}_{2}$ emission levels accompany small increases in per capita income levels. This result contrasts with the standard EKC curve in that we do not find an inverted $U$ curve. Rather, we find that the curve is a flattened inverse-S shaped curve where the slope is positive everywhere, except for the inflection point where the slope is zero. A similar trend is observed when energy use (ENPC) is used to index the country's level of environmental pollution. From Figure 1, it is clear that the ENPC curve is similar to the $\mathrm{CO}_{2}$ curve though flatter and less variable. In this case, the inflection point of the curve is at income level $\$ 13323$ which is not too far away from the inflection point in the $\mathrm{CO}_{2}$ curve.

The results imply that we can partition the environmental stress experience of countries into two distinct phases. During the first phase when per capita incomes are low. environmental stress is shown to increase but at a diminishing rate. During the second 
phase, per capita income is higher and environmental stress is observed to increase at an increasing rate. The results show that the impact of income on the environment is more significant on the extreme ends of the income scale. This means that there is relatively little change in the environmental stress levels for the middle-income countries. In contrast, the very low and very high income countries tend to experience rapidly increasing stress levels in their environmental conditions.

The results for $\mathrm{CO}_{2}$ and ENPC show that population density is positively related to environmental stress while the level of economic inequality and level of environmental stress are inversely related. Hence, as a country gets more crowded (more people per a fixed area of land), the higher will be their $\mathrm{CO}_{2}$ emission level and per capita energy use. This can be due to the fact that as population density increases, there is increasing pressure to use the existing land more intensively. The creation of multistory residential and commercial buildings in high population density countries is a good example of this problem. Lifestyle adjustments for residents in these countries imply more energy consumption and this leads to abnormally high levels of $\mathrm{CO}_{2}$ emissions and ENPC levels. Singapore is a case in point: its population density in 1995 was 4990 persons per square kilometer and the commercial energy use was $7162 \mathrm{~kg}$ of oil equivalent per capita. In contrast, the corresponding average levels for our sample of 51 countries are 206.35 and 2849.80, respectively. Clearly, the high population density in Singapore exerts a major influence on its extremely high level of energy use. 
On the other hand, any improvement in the inequalities between the rich and the poor is found to be detrimental to the environment. While counter intuitive in the first instance, this would seem sensible because a move towards more equal standards of living implies more people are able to afford the use of electricity, cars and other luxuries - which leads to increased energy use and increased emission of carbon dioxide in the air. ${ }^{3}$ For such a cross section of countries, the explanatory power of these two models are fairly high ( $58 \%$ for $\mathrm{CO}_{2}$ and $71 \%$ for ENPC).

Equation (2) above was also applied to the data using other specific pollutants such as TSP, $\mathrm{SO}_{2}, \mathrm{NO}, \mathrm{EMW}$ and DEFRTE. The magnitude and signs of the estimated coefficients are very sensitive to the pollutant used, and are very unstable. Further, the explanatory power of the models is greatly reduced with F-test results simultaneously indicating invalid models. The results are clearly weak - and this is mainly attributed to the quality of the data available. We note that many environmental studies used $\mathrm{CO}_{2}$ and ENPC precisely because the data on these variables are well developed. Also, we note here that trend results are similar for $\mathrm{CO}_{2}$ and ENPC because $\mathrm{CO}_{2}$ is a major component of ENPC. As seen in Table 3, these are the only environmental stress variables that have a high and positive correlation between them.

Table ta presents the estimation results using 1980 data. The magnitude and signs are consistent with 1995 estimates. Income is shown to initially increase environmental

\footnotetext{
${ }^{3}$ This issue has been analysed in greater detail in Torras and Boyce (1998) and Scurggs (1998) with mixed results.
} 
stress, and then decrease after a certain turning point income. It is however noted that the estimated coefficients from this estimation are mostly insignificant. ${ }^{4}$

\section{Impact on Health}

Results of the two-stage least squares (2sls) estimation of equations (2) and (3) are presented in Table 5 . In these estimations, we use alternative indicators of a population's health status - namely, life expectancy, infant mortality rate and child (under 5 ) mortality rate - and treat the environment stress as an endogenous variable. The Wu-Hausman test for exogeneity show that the null hypothesis of an exogenous environmental stress variable is strongly rejected for all the alternative types of pollutants on the left hand side.

The top panel of Table 5 presents the results for 1995 when life expectancy is the health indicator used? In general, the environmental stress variables have the correct sign (negative) and are significant for certain pollutants such as $\mathrm{CO}_{2}$, TSP, EMW and ENPC. UPOP (the percent of population in urban centers) - can be either negative or positive. UPOP is significant for $\mathrm{CO}_{2}$ and ENPC. GNP is nearly always significant. Coefficients for levels of immunization (DPT) and education level (SEC) appear significant on occasion but there is no observed consistency. The signs, are however, consistent. When infant mortality is taken as the health indicator, we find that increases in TSP emissions, water pollutant emissions levels and deforestation rates lead to significantly high infant

\footnotetext{
tEquation (2) was also estimited using the log-linear functional form and using each of the alternative pollutant variables. Results for these are not presented here for space reasons. In brief. the results indicate that the signs of the estimated coefficients from the log-linear model are consistent with those of the linear model. However, the results are weaker than their linear counterparts.
} 
mortality, Coefficient estimates derived from the estimation of the model using the child mortality rates are very similar to the infant mortality results.

The results for the 1980 data, found in Table 5a, are relatively weak, compared to the 1995 results. Increase in $\mathrm{CO}_{2}$ emissions and energy use do lead to significant reduction in life expectancy and increases in per capita incomes significantly increase life expectancy.

To further examine whether isolating environmental stress does have a significant impact on health status, we need to compare our second stage results with those using health equation models that exclude environmental factors. The effect of income and other variables on health is thus analysed using Equation (3) minus the environmental variable $E_{i t}$ The estimated parameters presented in Table 6 show that income has a significant impact on increasing life expectancy and decreasing infant mortality rates. A $\$ 10000$ PPP increase in per capita GNP increases life expectancy by 13 years. If we compare this to the 2 sls results that include the effect of environmental stress on health, we find that the impact of income is not as strong. In this case, a $\$ 10000$ increase in per capita income results in only 5 years more in life expectancy, when $\mathrm{CO}_{2}$ is used. The equivalent increases in life expectancy when alternative pollutants are used in the 2 sls estimation are 6 years for energy use and 5 years for water pollutants.

In the same way, we find that when we exclude the environmental stress variables in the health equation, a $\$ 10000$ increase in the per capita income reduces infant mortality rates 
by 30 deaths per thousand live births, while under 5 mortality rates decrease even more (by 39 deaths per thousand live births). If we compare this results to the 2 sls regressions, we find that the impact of an income increase is highly variable across the alternative pollutants. The most plausible result comes from the use of ENPC variable which indicates that a $\$ 10000$ increase in per capita income results in the reduction of the infant mortality rates by only 3 deaths per thousand live births. The reduction in the impact of an increase in income on health gains appears to be absorbed by the environmental stress variables. In Table 5, for example, we can see that as total suspended particulates go up by 10000 units, life expectancy falls by 7 years and if energy use increases by 10000 units, life expectancy goes down by 14.6 years.

The results for 1980 are weak, although there is some indication that other development indicators, such as, education and immunization levels (other than income) capture the indirect effects of environmental variables on health levels if environmental variable is excluded from the specification. This is shown by the reduced values of the coefficients once environmental variables are included.

We also use log linear models to check for robustness of results. The estimated coefficients for $\log \mathrm{CO}_{2}$ and $\log$ ENPC have positive coefficients and are significant. This result does not conform to economic expectations. GNP is found to be significant in all cases. Using $\log \mathrm{TSP}, \log \mathrm{SO}_{2}, \log \mathrm{NO}$ and $\log \mathrm{EMW}$ as the environmental stress variable, it is found that the coefficients are negative and even significant (for log $\mathrm{SO}_{2}$ and $\log$ NO). Results of the $\log$ linear model under the alternative indicators of health 
(i.e. child mortality rate) show that the environmental variable is significant in explaining changes in health levels in a population. There are, however, some problems with the other explanatory variables which come out as not significant in the estimation.

\section{Conclusion and Further Research}

In this paper, we have studied the links between health status, income and environmental indicators of a country. We first look at the relationship between environment and income - the Environmental Kuznets Curve relationship. Our findings do not support the EKC hypothesis. This implies that low income countries cannot simply postpone attending to environmental concems in the hope that the environment will eventually improve with increased incomes. Health is a significant intervening variable and isolating the impact of environment on health is very important, particularly in the context of developing countries. We find that the gains in health obtained through improved incomes can be negated to a significant extent if the indirect effect of income, acting via the environment, is ignored. This study thus shows that policy makers who have chosen to pursue rapid growth strategies at the expense of the environment are not delivering the full realisable health gains that can be derived from higher incomes. Our results indicate that when environment is included as an explanatory endogenous variable in the health equation, then increases in income lead to less than half the expected increase in life expectancy rates than when the environment is ignored. There is also a significant reduction in infant mortality rates once the environmental variable is included (from 30 deaths per thousand to 3 deaths per thousand). This reduction in the impact of an increase in income on health gains appears to be absorbed by the environmental stress variable. Also environmental 
damage is bound to result in health problems for the domestic population. A less healthy labor force will not be able to increase productivity levels, and hence result in lesser income for the economy. Addressing chronic health problems for the population is also costly and will divert valuable resources from income generating investment projects. Clearly, policies for growth must incorporate appropriate programs for protection of the country's natural environment and this does not have to be at odds with growth and development targets.

One of the ways this research can be extended is to obtain time series data on environmental indicators and health status for varied countries along the development spectrum. As we are interested in different kinds of environmental indicators, obtaining data for all these indicators for many years is quite challenging. Most developing countries do not keep records of environmental variables and this hampers our objective here. However, with the continued improvements in data systems over time, this problem will be reduced and research on this can be encouraged. A second extension would be to create a single indicator or index that is good enough to capture the overall quality of a country's physical environment. Such an index would be useful for analyzing environmental issues within a country and can also provide important insights in crosscountry trends. 


\section{References}

Cropper, M.L, Simon. N.B,, Alberini, A \& Sharma, P.K., (1997), 'The Health Effects of Air Pollution in Delhi, India', Policy Research Working Paper 1860, The World Bank.

Chakrabarti, A, \& Rao, D.N., (1999), 'Measuring the Impact of Policy Variables on the Burden of Disease', mimeo, Jawaharlal Nehru University.

Dasgupta, S., Mody, A., Roy S. \& Wheeler, D., (1995), 'Environmental Regulation and Development: A Cross-Country Empirical Analysis, World Bank Working Paper.

Deaton, A., (1999), 'Inequalities in Income and Inequalities in Health', National Bureau of Economic Research, Working Paper 7141.

Deininger, K. \& Squire, L., (1996), 'Measuring Income Inequality: A New Data-base’, World Bank, Washington, D.C., mimeographed.

Feachem, R., Kjellstrom, F., Murray, C., Over, M. \& Phillips, M., (1992), The Health of Adults in the Developing World, Oxford: Oxford University.

Flegg, A. T., (1982), 'Inequality of Income, Illiteracy and Medical Care as Determinants of Infant Mortality in Underdeveloped Countries', Population Studies 36(3): 441-58.

Galeotti, M. \& Lanza, A., (1999), 'Desperately Seeking (Environmental) Kuznets', mimeo, International Energy Agency.

Gerdtham, U., Sogaard, J., Andersson, F \& Jonsson; B., (1992), 'An Econometric Analysis of Health Care Expenditure: A Cross-section Study of the OECD Countries', Journal of Health Economics, 11, 63-84.

Grossman, G., (1995), 'Pollution and Growth', in I.Goldin and L.A. Winters (eds.), The Economics of Sustainable Development, Paris: OECD, 19-46. 
Grossman, G. \& Kreuger, A.B., (1995), 'Economic Growth and the Environment', Quarterly Journal of Economics, 112, 353-377.

Hill, K. \& King, E., (1992), 'Women's Education in the Third World: An Overview', In Women's Education in Developing Countries: Barriers, Benefits and Policy, ed King, E. \& Hill, A.M, 1-50. Baltimore: the John Hopkins University Press for the World Bank.

Kakwani, N., (1993), 'Performance in Living Standards: An International Comparison', Joumal of Development Economics, 41(2) 307-36.

Kaufmann, R.K., Davidsdottir, B., Garnham, S. \& Pauly, P. (1998), "The determinants of Atmospheric $\mathrm{SO}_{2}$ Concentrations: Reconsidering the Environmental Kuznets Curve' Ecological Economics, 25, 209-220.

Kuznets, S., (1955), 'Economic Growth and Income Inequality', American Economic Review, 45(1), 1-28.

Magnani, E., (1998), 'The Environmental Kuznets Curve, Environmental Protection Policy and Income Distribution', Working Paper, University of New South Wales.

Panayotou, T., (1993), 'Empirical Tests and Policy Analysis of Environmental Degradation at Different Stages of Economic Development', Working Paper, Technology and Environment Programme, International Labour Office, Geneva.

Parpel, F. \& Pillai, V., (1986), 'Patterns and Determinants of Infant Mortality in Developing Nations, 1950-1975', Demagraphy 23(4):525-42.

Preston, S. (1980), 'Mortality Declines in Less Developed Countries', In Population and Economic Change in Developing Countries, ed. Easterlin, R, 289-360. Chicago: The University of Chicago. 
Pritchett, L \& Summers, L.H., (1996), 'Wealthier is Healthier', The Journal of Human Resources, XXXI (4), 841-868.

Rothman, D.S., (1998), 'Environmental Kuznets Curves - Real Progress or Passing the buck? A Case for Consumption-based Approaches', Ecological Economics, 25, 177 194.

Selden, T.M., and Song, D., (1994), 'Environmental Quality and Development: Is There a Kuznets Curve for Air Pollution Emissions?' Journal of Environmental Economics and Management, 27 (2). 147-62.

Subbarao, K., and Raney, L, (1995), 'Social Gains from Female Education: A CrossNational Study' Economic Development \& Cultural Change, 44 (1) 105-28.

Suri, V, Chapman, D., (1998), 'Economic Growth, Trade and Energy: Implications for the Environmental Kuznets Curve', Ecological Economics, 25, 195-208.

Torras, M. \& Boyce, J.K., (1998), 'Income, Inequality and Pollution: a Reassessment of the Environmental Kuznets Curve', Ecological Economics, 25, 147-160.

UNICEF, (1991 and 1992), The State of the World's Children. Oxford: Oxford University Press.

World Bank, (1992), World Development Report 1992: Development and the Environment, Oxford University Press, New York. 
Table 1. Distribution of Countries by Region and by Income Level

\begin{tabular}{lcccc}
\hline & \multicolumn{2}{c}{1995} & \multicolumn{2}{c}{1980} \\
\hline & $\mathrm{N}$ & $\%$ & $\mathrm{~N}$ & $\%$ \\
\hline All countries & $\mathbf{5 1}$ & $\mathbf{1 0 0}$ & $\mathbf{3 6}$ & $\mathbf{1 0 0}$ \\
\hline by Region & & & & \\
- Africa & 3 & 5.88 & 1 & 2.78 \\
- Asia & 9 & 17.65 & $\mathbf{9}$ & 25 \\
- Eastern Europe & 8 & 15.69 & 1 & 2.78 \\
- Latin America & 7 & 13.73 & 7 & 19.44 \\
- Middle East & 2 & 3.92 & 1 & 2.78 \\
- Europe \& North America & 22 & 43.14 & 17 & 47.22 \\
\hline by Income per capita & & & & \\
- High & 23 & 45.1 & $\mathbf{1 3}$ & 36.11 \\
- Medium & 16 & 31.37 & 5 & 13.89 \\
- Low & 12 & 23.53 & 18 & 50 \\
\hline
\end{tabular}

Table 2a. Summary Statistics, 1995

\begin{tabular}{lccccc}
\hline Variable & Code & $\begin{array}{c}\text { All } \\
\text { countries } \\
(\mathrm{N}=51)\end{array}$ & $\begin{array}{c}\text { High } \\
\text { Income } \\
(\mathrm{n}=23) \\
\text { Mean }\end{array}$ & $\begin{array}{c}\text { Medium } \\
\text { Income } \\
(\mathrm{n}=16)\end{array}$ & $\begin{array}{c}\text { Low } \\
\text { Income } \\
(\mathrm{n}=12)\end{array}$ \\
\hline Population & POP & 84.82 & 38.04 & 47.56 & 224.17 \\
Population Density & POPDEN & 206.35 & 354.13 & 64.94 & 111.67 \\
Total Urban Population & TUPOP & 41.07 & 29.66 & 33.04 & 73.66 \\
Gross National Product & GNP PPP & 629.45 & 858.15 & 315.13 & 610.22 \\
(Purchasing Power Parity) & & & & & \\
Gross National Product per capita & GNP PPP pc & 12204.31 & 20150.87 & 7513.75 & 3227.50 \\
(Purchasing Power Parity) & & & & & \\
Gini coefficient & GINI & 36.49 & 31.63 & 43.03 & 37.11 \\
Life expectancy & LEXP & 72.47 & 77.00 & 70.75 & 66.08 \\
Child immunization rate & DPT & 86.86 & 88.26 & 87.31 & 83.58 \\
Gross enrollment ratio & SEC & 85.94 & 109.39 & 70.94 & 61.00 \\
Infant mortality rate & IMR & 18.96 & 5.61 & 21.94 & 40.58 \\
Child mortality rate & CMR & 23.78 & 6.70 & 26.44 & 53.00 \\
C O ${ }_{2}$ emission per capita & CO & 6.99 & 10.07 & 5.61 & 2.92 \\
Total suspended particles & TSP & 1997.24 & 393.54 & 992.53 & 6410.60 \\
Sulfur Dioxide & SO & 476.92 & 159.55 & 410.70 & 1173.51 \\
Nitrogen Dioxide & NO & 692.97 & 534.57 & 558.20 & 1176.26 \\
Emission of organic water & EMW & 429.86 & 382.43 & 217.30 & 799.56 \\
pollutants & & & & & \\
Commercial energy use per capita & ENPC & 2849.80 & 4437.26 & 1940.13 & 1020.08 \\
Deforestation rate & DEFRTE & 0.19 & -0.36 & 0.53 & 0.80 \\
\hline
\end{tabular}


Table 2b: Summary Statistics, 1995

\begin{tabular}{|c|c|c|c|c|c|c|c|c|}
\hline & & $\begin{array}{c}\text { All } \\
\text { countries } \\
(\mathrm{N}=51)\end{array}$ & $\begin{array}{l}\text { Africa } \\
(n=3)\end{array}$ & $\begin{array}{l}\text { Asia } \\
(n=9)\end{array}$ & $\begin{array}{c}\text { Eastem } \\
\text { Europe } \\
(n=8)\end{array}$ & $\begin{array}{c}\text { Latin } \\
\text { America } \\
(n=7)\end{array}$ & $\begin{array}{l}\text { Middle East } \\
\qquad(\mathrm{n}=2)\end{array}$ & $\begin{array}{l}\text { Europe } \\
\& \text { North } \\
\text { America } \\
(n=22) \\
\end{array}$ \\
\hline Variable & Code & Mean & Mean & Mean & Mean & Mean & Mean & Mean \\
\hline Population & POP & 84.82 & 27.67 & 298.33 & 32.50 & 53.43 & 61.00 & 36.45 \\
\hline Population Density & POPDEN & 206.35 & 53.33 & 751.11 & 89.88 & 30.00 & 50.00 & 117.05 \\
\hline Total Urban population & TUPOP & 41.07 & 11.03 & 100.74 & 23.28 & 41.81 & 31.90 & 27.82 \\
\hline $\begin{array}{l}\text { Gross National Product } \\
\text { (Purchasing Power Parity) }\end{array}$ & GNP PPP & 629.45 & 114.23 & 1187.41 & 139.06 & 389.94 & 252.25 & 760.28 \\
\hline $\begin{array}{l}\text { Gross National Product per capita } \\
\text { (Purchasing Power Parity) }\end{array}$ & GNP PPP pc & 12204.31 & 3456.67 & 10252.22 & 5578.75 & 7830.00 & 4110.00 & 18732.73 \\
\hline Gini coefficient & GINI & 36.49 & 50.13 & 39.09 & 27.12 & 52.88 & 37.62 & 31.67 \\
\hline Life expectancy & LEXP & 72.47 & 60.67 & 70.33 & 70.25 & 71.43 & 67.50 & 76.55 \\
\hline Child immunization rate & DPT & 86.86 & 57.33 & 91.11 & 93.25 & 84.43 & 95.00 & 86.86 \\
\hline Gross enrollment ratio & SEC & 85.94 & 48.33 & 69.00 & 84.00 & 56.57 & 71.50 & 109.36 \\
\hline Infant mortality rate & IMR & 18.96 & 59.00 & 27.33 & 13.25 & 26.14 & 44.50 & 7.55 \\
\hline Child mortality rate & CMR & 23.78 & 88.67 & 33.56 & 16.63 & 30.71 & 51.50 & 8.82 \\
\hline $\mathrm{CO}_{2}$ emission per capita & $\mathrm{CO}_{2}$ & 6.99 & 2.93 & 5.88 & 7.48 & 3.49 & 2.95 & 9.30 \\
\hline Total suspended particles & TSP & 1997.24 & 834.43 & 7931.34 & 1060.82 & 1117.53 & 1142.77 & 426.32 \\
\hline Sulfur Dioxide & $\mathrm{SO}_{2}$ & 476.92 & 158.64 & 1376.79 & 371.32 & 279.00 & 1173.13 & 190.27 \\
\hline Nitrogen Dioxide & NO & 692.97 & 288.64 & 1417.16 & 456.51 & 687.25 & 0.00 & 602.65 \\
\hline Emission of organic water pollutants & EMW & 429.86 & 147.60 & 1092.36 & 216.95 & 216.29 & 150.07 & 335.96 \\
\hline Commercial energy use per capita & ENPC & 2849.80 & 868.67 & 2066.67 & 2852.13 & 1169.14 & 985.00 & 4143.77 \\
\hline Deforestation rate & DEFRTE & 0.19 & 0.60 & 1.13 & -0.09 & 0.76 & 0.90 & -0.39 \\
\hline
\end{tabular}


Table 2c. Summary Statistics, 1980

\begin{tabular}{lccccc}
\hline & & $\begin{array}{c}\text { All countries } \\
(\mathrm{N}=36)\end{array}$ & $\begin{array}{c}\text { High Income } \\
(\mathrm{n}=13)\end{array}$ & $\begin{array}{c}\text { Medium } \\
\text { Income }(\mathrm{n}=5)\end{array}$ & $\begin{array}{c}\text { Low Income } \\
(\mathrm{n}=18)\end{array}$ \\
\hline Variable & Code & Mean & Mean & Mean & Mean \\
\hline Population & POP & 81.97 & 41.62 & 30.11 & 373.60 \\
Population Density & POPDEN & 192.10 & 104.64 & 280.49 & 101.30 \\
Total Urban population & TUPOP & 31.35 & 31.86 & 17.17 & 81.06 \\
Gross National Product per capita & GNP PPP & 7640.56 & 12983.08 & 5602.22 & 1088.00 \\
(Purchasing Power Parity) & pc & & & & \\
CO emission per capita & CO 2 & 6.41 & 11.98 & 3.96 & 0.78 \\
Emission of organic water & EMW & 0.18 & 0.17 & 0.18 & 0.19 \\
pollutants & & & & & \\
Commercial energy use per & ENPC & 2335.50 & 4607.69 & 1275.17 & 245.00 \\
capita & & & & & \\
Life expectancy & LEXP & 68.69 & 74.46 & 67.78 & 57.00 \\
Child immunization rate & DPT & 61.53 & 82.08 & 55.94 & 36.00 \\
Gross enrollment ratio & SEC & 65.33 & 90.23 & 54.61 & 39.20 \\
Infant mortality rate & IMR & 36.06 & 10.08 & 38.83 & 93.60 \\
Gini coefficient & GINI & 39.10 & 33.04 & 43.93 & 37.41 \\
\hline
\end{tabular}

Table 2d: Summary Statistics, 1980

\begin{tabular}{|c|c|c|c|c|c|c|c|c|}
\hline 1 & & $\begin{array}{c}\text { All } \\
\text { countries } \\
(\mathrm{N}=36)\end{array}$ & $\begin{array}{l}\text { Africa } \\
(n=1)\end{array}$ & $\begin{array}{c}\text { Asia } \\
(n=9)\end{array}$ & $\begin{array}{l}\text { Eastern } \\
\text { Europe } \\
(\mathbf{n}=1)\end{array}$ & $\begin{array}{c}\text { Latin } \\
\text { America } \\
(\mathrm{n}=7)\end{array}$ & $\begin{array}{l}\text { Middle } \\
\text { East }(n=2)\end{array}$ & $\begin{array}{l}\text { OECD } \\
(n=17)\end{array}$ \\
\hline Variable & Code & Mean & Mean & Mean & Mean & Mean & Mean & Mean \\
\hline Population & POP & 81.97 & 11.00 & 231.33 & 11.00 & 39.71 & 41.00 & 31.06 \\
\hline Population Density & POPDEN & 192.10 & 47.20 & 572,32 & 115.95 & 20.98 & 41.06 & 83.16 \\
\hline Total Urban Popn & TUPOP & 31.35 & 3.40 & 58.76 & 6.10 & 27.14 & 17.90 & 22.49 \\
\hline GNP per capita PPP & $\begin{array}{c}\text { GNP PPP } \\
\text { pc }\end{array}$ & 7640.56 & 1450.00 & 3945.56 & 4870.00 & 5722.86 & 1370.00 & 11282.35 \\
\hline $\mathrm{CO}_{2}$ emission p.c. & $\mathrm{CO}_{2}$ & 6.41 & 0.20 & 3.40 & 7.70 & 2.96 & 1.10 & 10.04 \\
\hline $\begin{array}{l}\text { Emission of organic } \\
\text { water pollutants }\end{array}$ & EMW & 0.18 & 0.20 & 0.17 & 0.15 & 0.20 & 0.19 & 0.17 \\
\hline $\begin{array}{l}\text { Commercial energy } \\
\text { use per capita }\end{array}$ & ENPC & 2335.50 & 121.00 & 962.89 & 2667.00 & 1082.71 & 371,00 & 3804.35 \\
\hline Life expectancy & LEXP & 68.69 & 53.00 & 64.56 & 70.00 & 66.57 & 56.00 & 73.35 \\
\hline $\begin{array}{l}\text { Child immunization } \\
\text { rate }\end{array}$ & DPT & 61.53 & 7.00 & 50.78 & 99.00 & 42.43 & 84.00 & 77.06 \\
\hline Gross enrollment ratio & SEC & 65.33 & 41.00 & 52.78 & 70.00 & 43.71 & 50.00 & 82.94 \\
\hline Infant mortality rate & IMR & 36.06 & 100.00 & 47.22 & 23.00 & 47.57 & 120.00 & 17.47 \\
\hline Gini coefficient & GINI & 39.10 & 36.74 & 40.10 & 32.24 & 49.53 & 42.00 & 34.64 \\
\hline
\end{tabular}


Table 3: Correlation between Environmental Indicators

\begin{tabular}{llllll}
\hline & $\mathrm{CO}_{2}$ & ENPC & TSP & $\mathrm{SO}_{2}$ & $\mathrm{NO}$ \\
$\mathrm{CO}_{2}$ & 1.0 & & & & \\
$\mathrm{ENPC}$ & 0.8942 & 1.0 & & & \\
$\mathrm{TSP}$ & -0.2720 & -0.3082 & 1.0 & & \\
$\mathrm{SO}_{2}$ & -0.1748 & -0.2331 & 0.8835 & 1.0 & \\
$\mathrm{NO}$ & -0.0912 & -0.1300 & 0.8196 & 0.8557 & 1.0 \\
\hline
\end{tabular}

Table 4: Results for Equation (2), 1995

\begin{tabular}{|c|c|c|c|c|c|c|c|}
\hline \multirow[b]{2}{*}{ Variable } & \multicolumn{7}{|c|}{ Dependent Variables } \\
\hline & $\mathrm{CO}_{2}$ & TSP & $\mathrm{SO}_{2}$ & NO & ENPC & EMW & DEFRTE \\
\hline Constant & 3.70 & $11646.21 * *$ & $1482.69 *$ & 1342.09 & $2023.34 * *$ & 1096870 & -0.130 \\
\hline GNP(PPP)pc & $0.002 * *$ & $-2.456^{* *}$ & -0.251 & -0.246 & $0.450^{* *}$ & -176.456 & $-5.4 \mathrm{E}-05$ \\
\hline$(\mathrm{GNP}(\mathrm{PPP}) \mathrm{pc})^{2}$ & $-1.25 \mathrm{E}-07^{* *}$ & $0.000155^{*}$ & 1.25E-05 & $1.42 \mathrm{E}-05$ & $-2.6 \mathrm{E}-05$ & 0.006021 & $-2.38 \mathrm{E}-09$ \\
\hline$(\mathrm{GNP}(\mathrm{PPP}) \mathrm{pc})^{3}$ & $3.08 \mathrm{E}-12^{* *}$ & $-3.01 \mathrm{E}-09$ & $-1.94 \mathrm{E}-10$ & $-2.30 \mathrm{E}-10$ & $6.43 \mathrm{E}-10$ & 2.25E-08 & $1.26 \mathrm{E}-13$ \\
\hline POPDEN & $0.001^{*}$ & 0.371 & -0.020 & -0.126 & 0.186 & -230.569 & $-3.57 \mathrm{E}-06$ \\
\hline GINI & $-0.126 * *$ & 10.235 & 6.485 & 9.768 & $-55.440^{* *}$ & 4519.812 & $0.026^{*}$ \\
\hline
\end{tabular}

*significant at $10 \%$ level ** significant at $5 \%$ level

Table 4a: Results for Equation (2), 1980

\begin{tabular}{lccc}
\hline & \multicolumn{3}{c}{ Dependent Variable } \\
\cline { 2 - 4 } & $\mathrm{CO}_{2}$ & \multicolumn{1}{c}{ EMW } & ENPC \\
\hline Constant & 4.694 & $0.152^{* *}$ & $1656.857^{*}$ \\
GNP(PPP)pc & 0.0013 & $-1.4 \mathrm{E}-05$ & 0.371252 \\
(GNP(PPP)pc) & $-8.90 \mathrm{E}-08$ & $1.75 \mathrm{E}-09$ & $-2.3 \mathrm{E}-05$ \\
(GNP(PPP)pc) & $4.48 \mathrm{E}-12$ & $-6.57 \mathrm{E}-14$ & $1.54 \mathrm{E}-09$ \\
POPDEN & $0.001737^{* *}$ & $-2.2 \mathrm{E}-05^{* *}$ & 0.077953 \\
GINI & -0.142 & $0.0015^{*}$ & $-46.384^{*}$ \\
\hline
\end{tabular}

*significant at $10 \%$ level **significant at $5 \%$ level 
Table 5: Results for Equation (3), 1995

\begin{tabular}{|c|c|c|c|c|c|c|c|}
\hline \multicolumn{8}{|c|}{ Dependent Variable: Life Expectancy } \\
\hline Variable & $\mathrm{CO}_{2}$ & TSP & $\mathrm{SO}_{2}$ & NO & ENPC & EMW & DEFRTE \\
\hline Constant & $57.04^{* *}$ & $62.30^{* *}$ & $63.33^{* *}$ & $70.57^{* *}$ & $54.42 * *$ & $63.20^{* *}$ & $58.20^{* *}$ \\
\hline $\begin{array}{l}\text { Environmental } \\
\text { Stress Variable }\end{array}$ & -0.24726 & $-0.00071^{*}$ & -0.00615 & -0.00769 & $-0.00146^{*}$ & $-4.45 \mathrm{E}-06^{*}$ & -2.77293 \\
\hline DPT & $0.059^{*}$ & $0.010^{*}$ & 0.120 & 0.054 & $0.075^{* *}$ & 0.064 & $0.105^{*}$ \\
\hline SEC & $0.032^{*}$ & 0.020 & 0.026 & 0,015 & $0.049 * *$ & 0.020 & -0.017 \\
\hline UPOP & $4.705^{*}$ & -5.373 & -6.284 & -6.468 & $5.678^{*}$ & -3.065 & 3.619 \\
\hline GNP(PPP)pc & $0.0005^{* *}$ & $0.0004 * *$ & 0.0003 & 0.0004 & $0.0006 * *$ & $0.0005^{* *}$ & $0.0004 * *$ \\
\hline \multicolumn{8}{|c|}{ Dependent Variable: Infant Mortality Rate } \\
\hline Variable & $\mathrm{CO}_{2}$ & TSP & $\mathrm{SO}_{2}$ & NO & ENPC & EMW & DEFRTE \\
\hline Constant & $75.05^{* *}$ & $59.83 * *$ & 56.008 & 24.68 & $76,42^{* *}$ & $58.05^{* *}$ & $74.12 * *$ \\
\hline $\begin{array}{l}\text { Environmental } \\
\text { Stress Variable }\end{array}$ & -0.670 & $0.003 * *$ & 0.023 & 0.032 & -0.0003 & $1.69 \mathrm{E}-05^{*}$ & $20.337^{*}$ \\
\hline DPT & -0.184 & $-0.379 *$ & -0.456 & -0.206 & -0.196 & -0.291 & $-0.582^{*}$ \\
\hline $\mathrm{SEC}$ & $-0.186^{* *}$ & -0.140 & -0.164 & -0.117 & $-0.184^{* *}$ & -0.114 & 0.173 \\
\hline UPOP & $-18.124 *$ & 11.264 & 14.507 & 18.049 & $-21,488^{*}$ & 6.338 & -24.426 \\
\hline GNP(PPP)pc & $-0.0006^{*}$ & $-0.0007 *$ & -0.0004 & -0.0010 & -0.0008 & $-0.0013 * *$ & -0.0006 \\
\hline \multicolumn{8}{|c|}{ Dependent Variable: Child (under 5) Mortality Rate } \\
\hline Variable & $\mathrm{CO}_{2}$ & TSP & $\mathrm{SO}_{2}$ & NO & ENPC & EMW & DEFRTE \\
\hline Constant & $113.69^{* *}$ & $88.95 * *$ & 85.63 & 41.08 & $118.67^{* *}$ & $83.74^{* *}$ & $111.88^{* *}$ \\
\hline $\begin{array}{l}\text { Environmental } \\
\text { Stress Variable }\end{array}$ & -0.657 & $0.004^{* *}$ & 0.033 & 0.045 & 0.001 & $2.37 \mathrm{E}-05$ & 26.134 \\
\hline Dpt & $-0,431 * *$ & $-0.723^{* *}$ & -0.811 & -0.455 & $-0.465 * *$ & -0.520 & $-0.937 * *$ \\
\hline $\mathrm{Sec}$ & $-0.219^{* *}$ & -0.147 & -0.186 & -0.120 & $-0.235^{* *}$ & -0.122 & 0.244 \\
\hline Upop & -28.885 & 18.828 & 19.356 & 24.326 & $-34.755^{* *}$ & 7.329 & -35.808 \\
\hline GNP(PPP)pc & -0.0008 & -0.0009 & -0.00035 & -0.001 & -0.001 & $-0.002 * *$ & -0.00072 \\
\hline
\end{tabular}

*significant at $10 \%$ level **significant at $5 \%$ level

The quadratic and cubic terms of income are dropped, as they do not come out to be significant in our models. 
Table 5a: Results for Equation (3), 1980

\begin{tabular}{|c|c|c|c|}
\hline \multicolumn{4}{|c|}{ Dependent Variable: Life Expectancy } \\
\hline Variable & $\mathrm{CO}_{2}$ & EMW & ENPC \\
\hline Constant & $52,00^{* *}$ & $52.78^{* *}$ & $52.31 * *$ \\
\hline Environmental Stress Variable & -0.714 & 5.857 & $-0.00295 * *$ \\
\hline DPT & $0.062^{*}$ & 0.046 & $0.067 * *$ \\
\hline SEC & 0.069 & 0.061 & 0.061 \\
\hline UPOP & 5.678 & 5.243 & 1.625 \\
\hline GNP(PPP)pc & $0.0012 * *$ & $0.0006 * *$ & $0.0019^{* *}$ \\
\hline \multicolumn{4}{|c|}{ Dependent Variable: Infant Mortality Rate } \\
\hline Variable & $\mathrm{CO}_{2}$ & EMW & ENPC \\
\hline Constant & $110.74 * *$ & 55.315 & $113.63^{* *}$ \\
\hline Environmental Stress Variable & 1.802 & 226.524 & $0.014^{*}$ \\
\hline DPT & -0.221 & -0.085 & -0.281 \\
\hline SEC & $-0.407^{*}$ & -0.345 & -0.387 \\
\hline UPOP & -25.0004 & -18.884 & -7.582 \\
\hline GNP(PPP)pc & .0 .004 & $-0.00257^{*}$ & $-0.0081 * *$ \\
\hline
\end{tabular}

* significant at $10 \%$ level **significant at $5 \%$ level 
Table 6: Results for Equation (3) minus environmental variables, 1995

\begin{tabular}{|c|c|c|c|}
\hline \multirow[b]{2}{*}{ Variable } & \multicolumn{3}{|c|}{ Dependent Variable } \\
\hline & Life Expectancy & Infant Mortality Rate & $\begin{array}{l}\text { Child (under 5) } \\
\text { Mortality Rate }\end{array}$ \\
\hline Constant & $57.12^{* *}$ & $78.34 * *$ & $118.14^{* *}$ \\
\hline GNP(PPP)pc & $.0013^{* *}$ & $-.0030^{* *}$ & $-.0039 * *$ \\
\hline$(\mathrm{GNP}(\mathrm{PPP}) \mathrm{pc})^{2}$ & $7.90 \mathrm{E}-08$ & $-1.51 \mathrm{E}-07 * *$ & $-2.16 \mathrm{E}-07^{* *}$ \\
\hline$(\mathrm{GNP}(\mathrm{PPP}) \mathrm{pc})^{3}$ & $-2.55 \mathrm{E}-12$ & $4.85 \mathrm{E}-12^{* *}$ & $7.21 \mathrm{E}-12^{* *}$ \\
\hline DPT & $.094 * *$ & $-.275^{* * *}$ & $-.558 * *$ \\
\hline SEC & -.013 & -.105 & -.0950 \\
\hline UPOP & 3.414 & -22.619 & -33.470 \\
\hline \multicolumn{4}{|c|}{${ }^{*}$ significant at $10 \%$ level $* *$ significant at $5 \%$ level } \\
\hline 1980 & \multicolumn{3}{|c|}{ Dependent Variable } \\
\hline Variable & Life Expectancy & Infant Mortality Rate & $\begin{array}{l}\text { Child (under 5) } \\
\text { Mortality Rate }\end{array}$ \\
\hline Constant & $54.347 * *$ & $104.766^{* *}$ & $165.744^{* *}$ \\
\hline GNP(PPP)pc & $5.03 E-12 * *$ & $-1.85 \mathrm{E}-11$ & $-6.56 \mathrm{E}-12$ \\
\hline$(\mathrm{GNP}(\mathrm{PPP}) \mathrm{pc})^{2}$ & $2.52 \mathrm{E}-07^{* *}$ & $-1.02 \mathrm{E}-06^{* *}$ & $-6.60 \mathrm{E}-06$ \\
\hline$(\mathrm{GNP}(\mathrm{PPP}) \mathrm{pc})^{3}$ & $-1.53 \mathrm{E}-11 * *$ & $6.22 \mathrm{E}+11^{* *}$ & $5.11 \mathrm{E}-10$ \\
\hline DPT & $0.061 * *$ & -0.245 & -0.419 \\
\hline SEC & 0.053 & -0.365 & -1.276 \\
\hline UPOP & 0.793 & -5.698 & 120.720 \\
\hline
\end{tabular}

*significant at $10 \%$ level ** significant at $5 \%$ level 


\section{Appendix}

Table A1. Countries included in the study.

\begin{tabular}{llllll}
\hline 1 & Argentina & 14 & Ecuador & 27 Kenya* & 40 South Africa* \\
2 & Australia & 15 Egypt, Arab Rep. & 28 Korea, Rep. & 41 Spain \\
3 & Austria & 16 Finland & 29 Malaysia & 42 Sweden \\
4 & Belgium & 17 France & 30 Mexico & 43 Switzerland* \\
5 & Brazil & 18 Germany* & 31 Netherlands & 44 Thailand \\
6 & Bulgaria* & 19 Greece & 32 New Zealand & 45 Turkey \\
7 & Canada & 20 Hungary & 33 Norway & 46 Ukraine* \\
8 & Chile & 21 India & 34 Philippines & 47 United Kingdom \\
9 & China & 22 Indonesia & 35 Poland* & 48 United States \\
10 Colombia & 23 Iran, Islamic Rep.* 36 Portugal & 49 Venezuela \\
11 & Croatia* & 24 Ireland & 37 Romania* & 50 Ghana \\
12 & Czech Republic* & 25 Italy* & 38 Russian Federation* 51 Slovak Republic* \\
13 Denmark & 26 Japan & 39 Singapore & \\
\hline
\end{tabular}

*Included in 1995, excluded in 1980 analysis.

Table A2. Variable Details

\begin{tabular}{|c|c|c|c|}
\hline Variable Name & Code & Other Details & Source \\
\hline \multicolumn{4}{|c|}{ Environmental Stress Variables } \\
\hline Carbon dioxide & $\mathrm{CO}_{2}$ & Emissions per capita, metric tons, 1995 & World Bank \\
\hline Total suspended particles & TSP & Microgram per cubic meter, 1995 & World Bank \\
\hline Sulfur dioxide & $\mathrm{SO}_{2}$ & Microgram per cubic meter, 1995 & World Bank \\
\hline Nitrogen dioxide & NO & Microgram per cubic meter, 1995 & World Bank \\
\hline Commercial energy use & ENPC & $\begin{array}{l}\text { Emissions per capita, kilograms of oil } \\
\text { equivalent } 1995\end{array}$ & World Bank \\
\hline Organic water pollutants & EMW & Kilograms per day $1980 \& 1993$ & World Bank \\
\hline Annual deforestation rate & DEFRTE & Average $\%$ change $1990-95$ & World Bank \\
\hline \multicolumn{4}{|c|}{ Health and Other Development Indicators } \\
\hline Life expectancy & LEXP & Years, 1996 & World Bank \\
\hline Infant mortality rate & IMR & Per 1000 live births. 1996 & World Bank \\
\hline Child mortality rate & CMR & Per 1000,1996 & World Bank \\
\hline Child immunisation & DPT & $\%$ of children under 12 months, 1995 & World Bank \\
\hline Gross National Product & GNP & $\begin{array}{l}\text { Per capita, purchasing power parity, } \\
1996\end{array}$ & World Bank \\
\hline Urban Population & UPOP & $\%$ of total population, 1996 & World Bank \\
\hline Population Density & POPDEN & People per square kilometre, 1996 & World Bank \\
\hline Gross enrollment ratio & SEC & $\begin{array}{l}\text { Secondary level, \% of relevant age } \\
\text { group, } 1995\end{array}$ & World Bank \\
\hline Gini coefficient & GINI & N/A & $\begin{array}{l}\text { Deininger \& } \\
\text { Squire (1996), } \\
\text { World Bank }\end{array}$ \\
\hline
\end{tabular}


Figure 1. Estimated Relationship between $\mathrm{CO}_{2}, \mathrm{ENPC}$ and Income

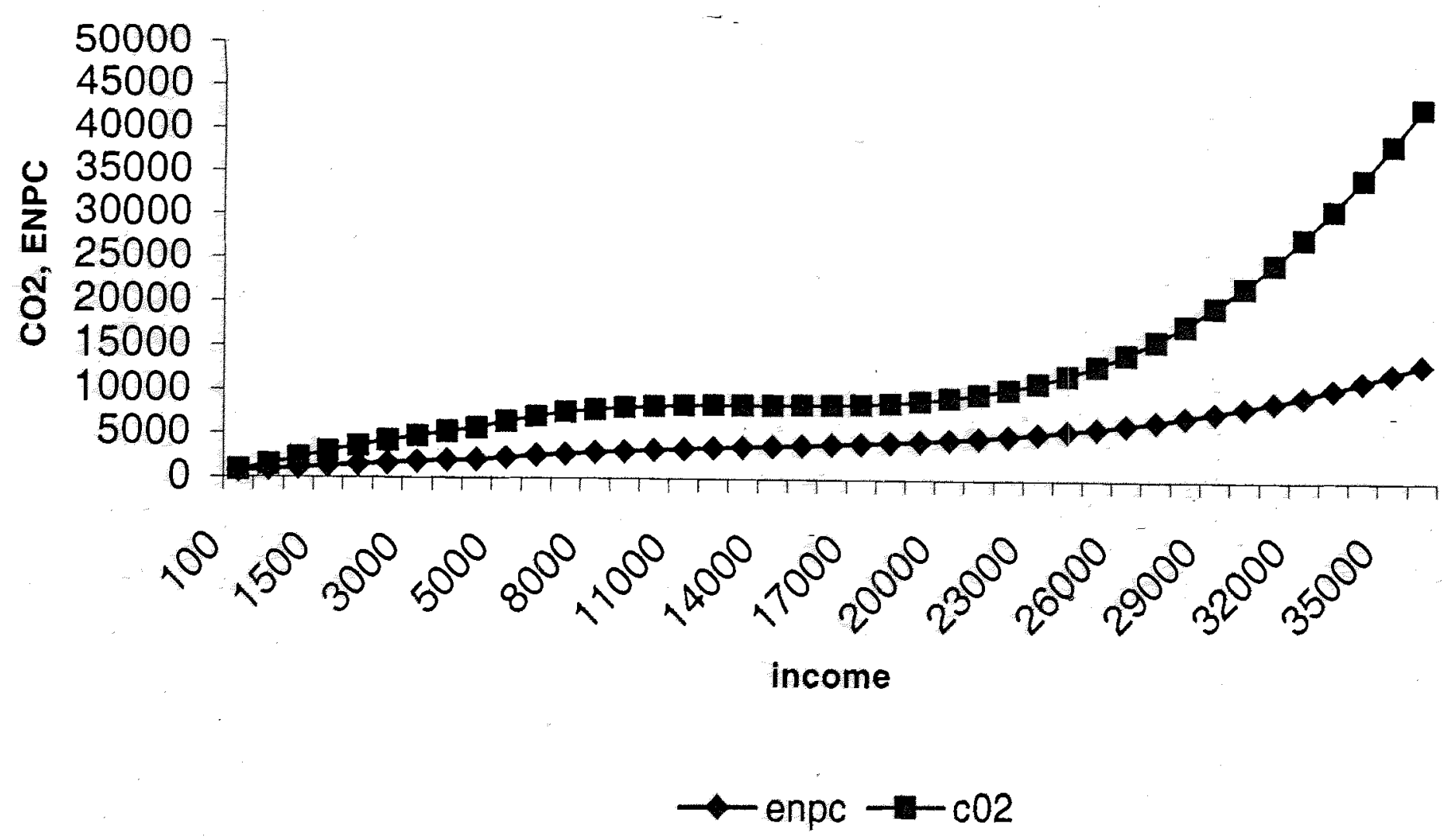


Figure 2. Estimated Relationship between heatlh indicators and income

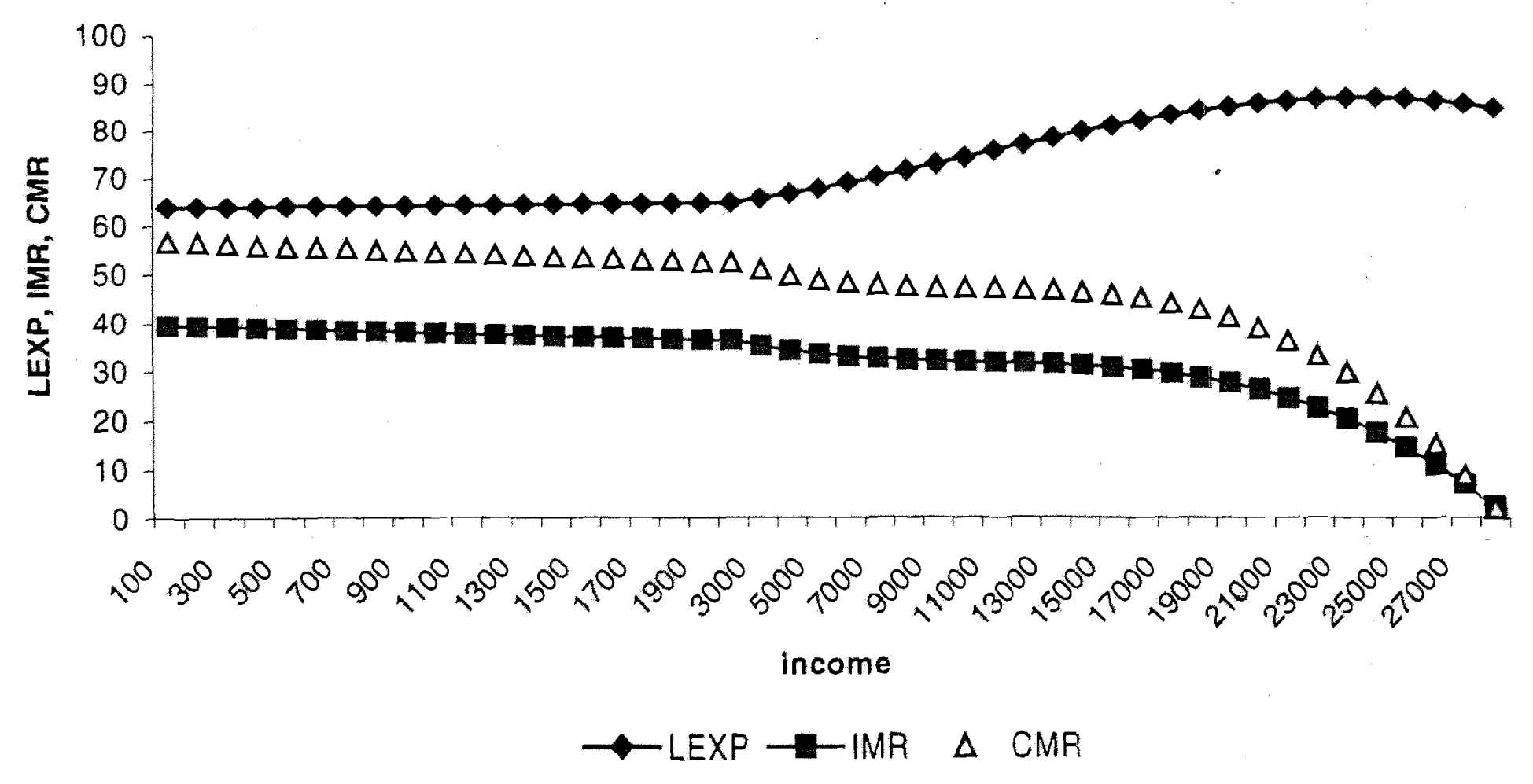




\begin{tabular}{|c|c|c|c|c|c|c|}
\hline No. & AUTHOR/S & TITLE' ' ' & DATE & $\begin{array}{l}\text { INTERNAT. } \\
\text { WORKING } \\
\text { PAPER NO. }\end{array}$ & ISBN NO. & \\
\hline 732 & $\begin{array}{l}\text { J. G. Hirschberg } \\
\text { \& P. J. Lloyd }\end{array}$ & $\begin{array}{l}\text { An Application of Post-Dea Bootstrap Regression Analysis } \\
\text { to the Spill over of the Technology of Foreign-Invested } \\
\text { Enterprises in China }\end{array}$ & January 2000 & IWP 669 & 0734016735 & 29 \\
\hline 733 & $\begin{array}{l}\text { Chris Brooks \& } \\
\text { Olan T. Henry }\end{array}$ & $\begin{array}{l}\text { The Impact of News on Measures of Undiversifiable Risk: } \\
\text { Evidence from the UK Stock Market }\end{array}$ & February 2000 & IWP 670 & 0734016743 & 28 \\
\hline 734 & $\begin{array}{l}\text { Joshua S. Gans \& } \\
\text { Stephen P. King }\end{array}$ & $\begin{array}{l}\text { Mobile Network Competition, Customer Ignorance and } \\
\text { Fixed-to-Mobile Call Prices }\end{array}$ & February 2000 & IWP 671 & 0734016751 & 31 \\
\hline 735 & $\begin{array}{l}\text { Jose-Luis Negrin \& } \\
\text { Charles E. Hyde }\end{array}$ & Access Pricing: A Survey & February 2000 & IWP 672 & $073401676 X$ & 35 \\
\hline 736 & $\begin{array}{l}\text { Rob Feeney \& } \\
\text { Stephen P. King }\end{array}$ & Sequential Parimutuel Games & February 2000 & IWP 673 & 0734016778 & 12 \\
\hline 737 & $\begin{array}{l}\text { Robert Dixon, } \\
\text { David Shepherd \& } \\
\text { James Thomson }\end{array}$ & Regional Unemployment Disparities & February 2000 & IWP 674 & 0734016786 & 26 \\
\hline 738 & $\begin{array}{l}\text { Olan T. Henry \& } \\
\text { Peter M. Summers }\end{array}$ & $\begin{array}{l}\text { Australian Economic Growth: Non-linearities and } \\
\text { International Influences }\end{array}$ & $\operatorname{March} 2000^{=}$ & IWP 675 & 0734016794 & 18 \\
\hline 739 & $\begin{array}{l}\text { Joshua S. Gans \& } \\
\text { Stephen P. King }\end{array}$ & $\begin{array}{l}\text { Using Bill and Keep' Interconnect Arrangements to } \\
\text { Soften Network Competition }\end{array}$ & March 2000 & IWP 676 & 0734016808 & 12 \\
\hline 740 & $\begin{array}{l}\text { Lata Gangadharan } \\
\text { \& Ma. Rebecca } \\
\text { Valenzuela }\end{array}$ & $\begin{array}{l}\text { Intertelationships between Income, Health and the } \\
\text { Environment: Extending the Environmental Kuznets Curve } \\
\text { Hypothesis }\end{array}$ & March 2000 & IWP 677 & 0734016816 & 35 \\
\hline
\end{tabular}

